FACTA UNIVERSITATIS

Series: Philosophy, Sociology, Psychology and History Vol. 19, N 1, 2020, pp. 27 - 44 https://doi.org/10.22190/FUPSPH2001027J

Original Scientific Paper

\title{
FELLOW TRAVELERS FROM SERBIA: LGBT-IDENTIFIED PERSONS AND THE CHURCH IN THE PROCESS OF EUROPEANIZATION
}

\author{
UDC 2-055.3(497.11)
}

\author{
Miloš Jovanović. Nemanja Krstić \\ University of Niš, Faculty of Philosophy, Department of Sociology, Serbia
}

\begin{abstract}
The paper deals with the question of the dynamics of relations between the political power elite, the LGBT population and the Serbian Orthodox Church in the overall context of the Europeanization of Serbia. An insight is provided into the mechanism(s) through which the political elite in Serbia reproduces its dominant position. Serbian society is depicted as a captured one, and this is illustrated by empirical findings from a survey and in-depth interviews. This is followed by a focus on the political elite's instrumentalization of the issue of sexual freedom in obtaining international support for maintenance of power through "tactical Europeanization". After this the position of the Serbian Orthodox Church vis-à-vis the state and its alleged support for LGBT issues is considered. The Church seems to have "realized" that being silent on the LGBT issue is more profitable in a symbolic, as well as, in a material sense.
\end{abstract}

Key words: Serbia, Europeanization, Power elite, LGBT population, Serbian Orthodox Church

\section{INTRODUCTION}

This chapter will focus on the dynamics of relations between the state, the Serbian Orthodox Church, and LGBT-identified persons in present-day Serbia in the context of the process of Europeanization - a process in which states adopt EU rules. The main goal of the text is to provide an insight into the mechanism(s) through which the political elite in Serbia manages the intra-state processes - including the positioning of the dominant religious institution and the changing status of sexual minorities - in order to reproduce its dominant position in circumstances primarily shaped by the Europeanization of the country. In addition, we want to show that the imposition of the agenda (through the selection and popularization of certain topics in the public sphere), as well as the way of

Received January 24, 2020 / Accepted May 25, 2020

Corresponding author: Miloš Jovanović

University of Niš, Faculty of Philosophy, Cirila i Metodija 2, 18000 Niš, Serbia

E-mail: milos.jovanovic@filfak.ni.ac.rs 
implementing specific formal regulations related to the LGBT population's life, depends primarily on the interests of the political elite, and not the interests of other social actors or the potential contribution of these measures to the democratization of society. All this is illustrated by media reports on events related to the organization of the Pride Parade, changes and effects of legal and other norms aimed at improving the status of nonheterosexuals, and the absence of reaction from the Serbian Orthodox Church to this.

The main argument is that the case of promotion of the rights and the fight against discrimination of sexual minorities is symptomatic of the arbitrary legitimization of certain social actors by the political authorities in Serbia when it is for the benefit of their interests, that is, for arbitrary discrediting, ignoring or removal from the public sphere of those actors whose interests are not in line with those of the political elite.

The designation of LGBT persons and the Church as "fellow travelers" in the title refers to the situation in which the former are very willing travelers on this journey, while the latter is an ambivalent and somewhat reluctant itinerant ${ }^{1}$. The Serbian state presents the political frame, or to continue with the metaphor - "the vehicle" of this voyage. As the "means of transportation" affects the quality of the passengers' journey to a great extent, we shall, after a section depicting our research methodology, start with a short portrayal of some of the state's key political features. This will be followed by a segment devoted to "tactical Europeanization" - a process through which politicians manifest their alleged commitment to EU principles, without true devotion to their implementation. In the end, we turn to the Serbian Orthodox Church and its relation to the government, which, in turn, effects the stance the Church publicly takes on LGBT issues.

\section{Methodology}

The arguments offered in the text are conceived so that they represent one type of methodological triangulation (Jick 1979). Namely, in order to validate basic assertions, we have used an analysis of data obtained from three sources: survey research, group and individual interviews, and media content analysis. Depending on the argument presented in the text, the data from these sources most often complemented each other, while in a limited number of cases where there were no multiple data types related to the same topic, one source was used.

The survey research was carried out on a representative sample of 6,040 citizens of Albania, Bosnia and Herzegovina, Kosovo, Macedonia, Montenegro and Serbia over the age of $18^{2}$. The data was collected during the period May-June $2017^{3}$. The questionnaire included questions related to attitudes towards types of governance, the experience of the

\footnotetext{
1 "[B]oth among the public, as well as in academia, the Serbian Orthodox Church is seen as a closed, nationalistic, and homogeneous institution, an anti-EU institution, closely allied with the government" (Brujić 2017, 36). However, there exist "both isolationist and pro-European factions among clergymen in the Serbian Church. In fact, like the Serbian public, the Church remains profoundly ambivalent with regard to EU membership (...) What is quite clear from a recent research project regarding the role of the Church vis-à-vis Serbian EU membership is that the opinions of Orthodox believers are quite diverse, contradictory, and often ambiguous" (Brujić 2017, 35, 39; see also: Perica 2006).

21,127 of those from Serbia.

3 The sampling universe was based on the data from the Census and estimated population dynamics and a stratified three-stage random representative sample was used. In all the countries, CAPI (Computer-assisted personal interviewing) was used in conducting face-to-face interviews.
} 
respondents with the clientelist practices of getting various jobs done, and their attitude toward homosexuality.

The interviews and survey data we use in the analysis in this paper were conducted within the INFORM project. Interviews were conducted with "informality insiders/experts" and EU experts. "Insiders"/"informality experts" are people well acquainted with informal practices, being exposed to them in particular fields: local administration, government agencies, politics, healthcare, education, and the media. "Insiders" were identified either by personal knowledge on the part of the researchers or by having been named by interview respondents. It should be noted that out of ten, half were group interviews, so in these cases the data obtained was validated directly by confirming or challenging certain statements by other participants in the interview. The same method of validation, when needed, was used in individual interviews - important information (whether related to a particular event or a more complex practice or mechanism) obtained from one interviewee was cross-checked in conversation with other respondents. In addition to interviews with insiders, five interviews with EU experts were analyzed. These experts are people who were part of the process of European integration, either working in government teams or the non-governmental sector.

The third type of data was obtained by analyzing media content. First, using the Google search engine, we looked for electronically available press - news articles/announcements on a subject that we deal with, using pre-determined keywords or a combination of key words (Serbia, LGBT, gay, homosexuality, Serbian Orthodox Church, Church, Government, State). After a database of texts was created, all the items were analyzed and the selection of abstracts from these was made, using the criterion of objective and impartial reporting. It should be emphasized that these texts were published on news portals that are not connected to or under the influence of the government or the Church.

\section{SERBIA AS A CAPTURED SOCIETY}

The political system of Serbia has been marked by instability since the breakdown of socialism up to this day. Democracy has never been fully consolidated at any time since the beginning of the transition, and the political scene is dominantly characterized by the shifts of authoritarian party leaders, and the "authoritarian state structure remained untouched after 2000" (Jovanović 2018, 49).

The undeveloped democracy is accompanied by political voluntarism, a weakened civil society and pronounced social inequalities which are also reflected in discriminatory gender practices as well as in the violation of the rights of sexual minorities. The ruling political parties control local budgets, media, employment mechanisms, and court processes (Subotić 2017, 175) through clientelistic networks, thus capturing the society through control and a system of blackmail.

"The structural political problem that has allowed for such widespread corruption is the phenomenon of "state capture," defined as a "seizure of laws to the advantage of corporate business via influential political links in the parliament and government." As a consequence, government bodies became private fiefdoms of political parties, where predatory parties utilized state resources by, for example, seizing control of public companies, without any checks or balances" (Subotić 2017, 176). 
Political rights and civil liberties have declined in Serbia, so that, after fifteen years, the country is classified as "Partly Free," with a 6 point decline in Aggregate Score (Freedom House 2019, 6).

"Serbia's status declined from Free to Partly Free due to deterioration in the conduct of elections, continued attempts by the government and allied media outlets to undermine independent journalists through legal harassment and smear campaigns, and President Aleksandar Vučić's de facto accumulation of executive powers that conflict with his constitutional role" (Freedom House 2019: 13).

One can say it is difficult to find any field of public action which is not, directly or indirectly, under the influence of political actors. In their hands, the political elite, using state resources, monopolizes the possibilities and rights for establishing legal principles for the regulation of social relations and prioritizes issues which will be addressed. In this way, the elite establishes a kind of dominance in defining the moral order of society (Eisenstadt 1973).

An illustration of the importance of politics in the social life of Serbian citizens comes from data obtained in a survey we conducted in six Southeast European societies. Analysis of the data shows that their citizens feel that some of the key life goals cannot be achieved without politics. This is especially pronounced in the views and experiences of respondents from Serbia. We may use the opinion on employment channels in the state sector as an example. The vast majority of respondents think that access to positions in the state sector is possible only through membership in a political party (see Fig. 1.1), as most consider changes in employment status, whether positive or negative, are caused by the political affiliation of citizens (see Fig. 1.2).

BECOMING A MEMBER OF A POLITICAL PARTY TO GET A JOB

IN STATE/PUBLIC SECTOR OR ENTERPRISES

1 - does not occur at all/ 10 - occurs all the time

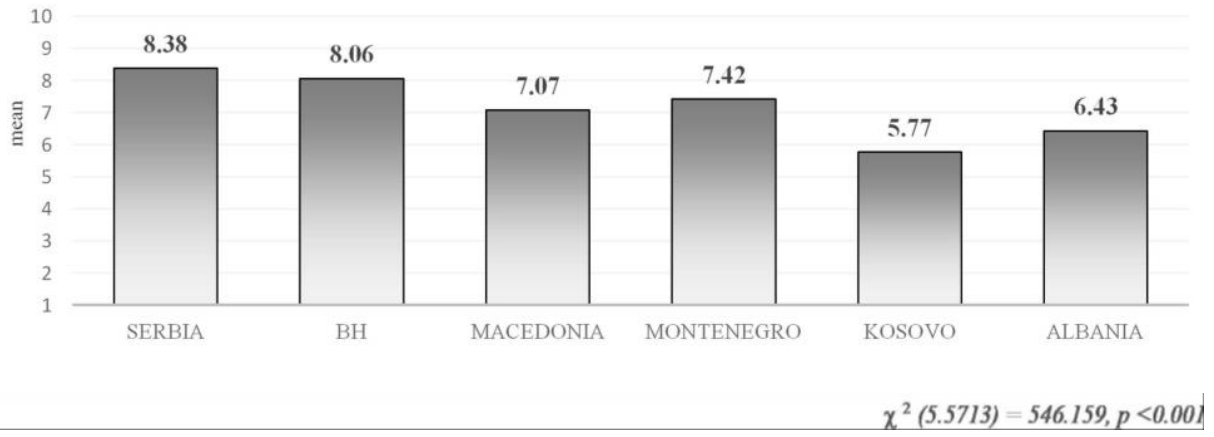

Fig. 1.1. Respondents' standpoint on the impact of membership in a political party for securing a job in the public or private sector 


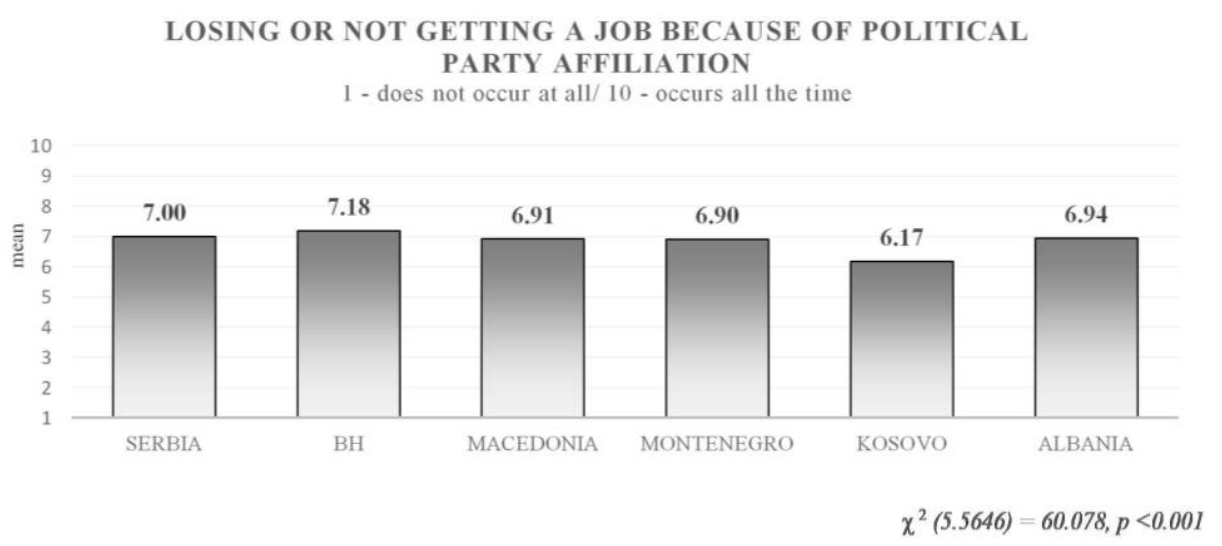

Fig. 1.2. Respondents' opinion on the importance of political affiliation for securing or losing a job

The survey respondents were also asked to evaluate, from 1 (never) to 10 (all the time), how often the following factors determine one's chances of getting employment: merit, party membership, connections, and bribery. In all the countries, merit-based employment is perceived to be the least common basis for employment. The other modes of employment are perceived to be much more common in all countries, with party membership being the highest in Serbia.

Such attitudes are confirmed by interviews with several research participants who have personal experience of working in the state and private sectors. One respondent told us about the difference between the principles upon which people are chosen to get a job in the private sector, in relation to the qualities which are important for someone to get a job in the public sector:

And now we are sitting in a privately-owned shop, and I even managed to educate my mom who is 87 years old so she hires neighbors and now wants to hire them here with her grandchildren. The grandchildren do not want to hear of it, because in order to get a job in a private company you have to show your quality. And in order to get a job with Aleksandar Vučić, you have to know him. That is the attitude towards the State (Srb_33; our translation).

Although the dominance of the political elite is evident, it is not absolute in all social fields. Therefore, due to the social circumstances in which there are elites that have established relative domination in other social fields, for example economic elites in the economic field, or ecclesiastical domination at the symbolic level ${ }^{4}$, the political elite is forced to negotiate with them on certain relevant topics and to establish a certain degree of autarchy ${ }^{5}$ in relation to them.

\footnotetext{
4 " $[\mathrm{N}] \mathrm{ations}$ of the former Yugoslavia need religion in order to transcend the post-transitional reality symbolically and ritually. Religion is the prime mover that sets all that is national in motion, yet at the same time it sets its ultimata, as traditional religious values are presented as the height of morality (...). Such religion and religiosity is of necessity ideologized, though declaring and presuming itself to be universal, transcendent and uncontaminated. It is presented as universal despite seeking to define key aspects of the ethnopolitical narrative" (Sremac et al. 2015, 53).

${ }^{5}$ For detailed clarification of the term 'autarchy' used in the paper, see: Lachmann 2011.
} 
The rise of religious nationalism in Serbia today is partly attributable to current postconflict and economic problems, notably the conversion from communism to nationalism, the establishment and expansion of religion as a new dominant ideology, and the failures of secular politicians to distance themselves from the church leaders (Valić-Nedeljković et al. 2017, 86-87).

An example of cooperation between the political and church elite is visible at all levels of political agency with an "increasing dissolution of the Church and state divide" (Subotić 2017, 182). ${ }^{6}$

"[F]rom the late 1980 s to very present, the Church has assumed an increasingly visible role in everyday life. For instance, among other such manifestations, can be mentioned radio and TV programs featuring priests, as well as the prominence of Orthodox themes in the media in general. This is especially true after 2000 , a time when the strong connection between the Church and the state became evident" (Brujić 2017, 36).

"It is noteworthy that diverse political changes in post-Milošević Serbia have influenced the relationship between church and state only to a minor degree. Even Zoran Đinđić, the most charismatic personality among the secular liberals until his assassination in 2003, was aware that he needed to cooperate with the SOC [Serbian Orthodox Church] in order to achieve political stability" (Buchenau 2014, 78).

Examples of this dissolution range from asking for a blessing from a current Patriarch, the leader of the national church ${ }^{7}$, when taking over presidential duties, through the repeal of the Law on the Prohibition of Discrimination from the Assembly Procedures at the request of the Serbian Orthodox Church (Jovanović 2013: 89-91), the celebrations of the parties' patron saints, to the fact that the "Serbian state has also financially supported the extraordinary expansion of new church construction throughout Serbia" (Subotić 2017, 182). However, according to the Serbian historian Radmila Radić:

[T] he Church of Serbia is a state religion and institution dependent on government financial support; that most clergy are state-salaried moderates and family men, and zealots are always minority groups of monks and monk-bishops. Hence the Church hardly ever contradicts the political authority of its "own state" and although its public statements are worded strongly it rarely makes a real difference in politics (Radić quoted in Perica 2006, 193).

It should be noted that due to the patrimonial structure of political authority, its symbolic legitimation by the church is being carried out at the level of both national and local governments. An interesting and particularly illustrative example of the link between local patrimonialism (Charrad 2011) and local church elite representatives can be found in a small town in the central part of Serbia. According to one informant, and confirmed by three others, the city patrimon was given a place in the liturgy because of

\footnotetext{
${ }^{6}$ The relationship of symphony between the Church and the State is viewed with nostalgia and is idealized: "Historically, the Orthodox Church functioned under the guiding principle of symphonia - symphony between the Church and State. Today, that same principle may be applied in providing understanding for the reemergence of the Church on the political scene in post-communist societies is specific, and in society at large. This, according to Bishop Atanansije (Jevtić) is not the 'politicization of the Church'; rather 'the Christianization of the world and of life"" (Dobrijević 2006: 330). "Eastern Churches are some kind of branches of government often under special laws. Also by tradition, Caesar is always first and the Patriarch (head of the Church) is the ruler's benevolent mentor" (Perica 2006, 176).

7 This practice has been established in recent history by Boris Tadić, who served two terms as President of Serbia in the period from 2004 to 2012.
} 
the help and support provided to the eparchy. The prayer service contained the name and surname of the then mayor ${ }^{8}$ :

The Church is a catastrophe, I mean ...Well, we are separated from the Niš eparchy. We have our own eparchy. The Church has a deal with politics... Do you know how each prayer begins? - God, give grace to our Mayor Bratislav Gašić. Then he goes on. Incredible. I mean, it's outrageous ... the man who is a member of this eparchy begins a prayer with those words. Anything that starts in town, the prayer begins with those words. It was a scandal at one point (Srb_60; our translation).

Although the political elite is in some social circumstances forced to negotiate with other elites, its ultimate interest is to maintain its independence in relation to them. An example of a mechanism by which central government marginalizes (Charrad 2011) representatives of the church elite, instrumentalizing the LGBT community for this purpose, is at the same time a process by which the political elite establishes autarchy. Namely, it is a process of distancing or, perhaps, even better, establishing control over the church elite in the field of sexual freedoms. The church discourse in the near past was characterized by distinct aggressiveness, moralistic condemnation (Jovanović 2011), and was very effectively distributed by the media without questioning or condemnation.

The mechanism of marginalization of the Church or other elites and the realization of autarchy has another purpose. It brings the political elite closer to the European Union officials and to meeting the conditions placed on the State authorities as a prerequisite for joining. Thus, the political elite acquires legitimation for its decisions and actions in relation to the international political context. In fact, it could be said that the constitution and maintenance of an authoritarian system of power in Serbia is, partly, a consequence of the formal rules laid down by the European Union on state institutions, which often overlook the essential nature of state power and the mechanisms of fictitious harmonization of the state legal system with the European Union one. As a consequence, such circumstances in Serbia have been weakening state institutions' democratic capacities and concentrating power in the hands of the political elite. Concentration of power, on the other hand, produces a strong internal hierarchy, which in practice means the embodiment of power in the personality of the "ideal" ruler (sovereign). This may best be illustrated by the opinion of an expert on European integration with whom we spoke:

"Well, there is hope, this stabilitocracy served by the European Union, it's happening in all the countries of the Western Balkans. They bring in a man with whom they speak, then give him absolute power and control over the whole country, local power and in the provinces and everything. He receives control over the media, the judiciary; the opposition is broken, which means all resistance, social, political. Then they say: you have to let it all go down the drain. And he does that. In my opinion, if there is a justification for installing such regimes, then this is because at one point the installer can force the application of everything that was signed. If that does not happen, then this country will perish permanently, the opening of any chapters will not matter. Here, now chapters will be opened one by one, probably a lot faster, I see that our people mass produce those negotiating positions, almost once a month. But in June many chapters will be opened in this intergovernmental convention, but it's nothing without application. What we agreed on. If this makes any sense, what is happening here is to break the resistance. If someone can reduce pensions and win the next election, he can do anything.

${ }^{8}$ The former Mayor still enjoys the status of "the man" or "the town sheriff", although he no longer occupies a high position in the local government, but is currently at the very top of the State government, the chief of the Security Intelligence Agency. 
If someone can appoint a gay prime minister in Serbia, he can do anything. Then he can depoliticize the judiciary, but he won't. Then he can choose a normal ombudsperson, but he won't"' (Srb_43; our translation).

Validation of these processes in the general population can be shown by the attitude of Serbian citizens towards the claim that "Having a strong leader who does not have to bother with Parliament and elections would be the best for our country". On a scale of one to five, where 1 marks complete disagreement, and 5 represents full agreement, respondents in Serbia have shown a greater inclination towards accepting this claim than towards its rejection $($ mean $=3.40)$.

In summary, the social context in which the process of harmonization of the Serbian legal system regulating the field of expression of sexual freedoms with the acquis communautaire is strongly determined by two tendencies. The first one is the tendency of the political elite to reach a high degree of autonomy in relation to all other significant social actors in the country. The second one is the political elite's instrumentalization of the issue of sexual freedom in obtaining international support for the maintenance of power. All this produces an illusion of democratization of the process of negotiating sexual freedoms, in which changes occur only at the level of discourse, but not in practice.

\section{TACTICAL EUROPEANIZATION AND LGBT PERSONS}

The stand that Serbia takes in relation to the LGBT population is paradigmatic for the more general process of Europeanization of this country: formal obligations are being fulfilled, but there is no major effort to bring about significant social changes. The adopted rules do not reach a "substantial level", and instead remain at the level of the "verbal" and formally "legal". Activities represented as positively oriented toward LGBT persons are short-term and superficial. The challenges and resistance of the government bodies and officials are not to be found at the level of official discourse, but instead at the level of practice (Ejdus and Božović 2016).

A number of laws have been passed which contain provisions focused on fighting discrimination against non-heterosexual persons ${ }^{10}$, programs have been realized and action plans made with the same goal in mind ${ }^{11}$, and also several Pride Parades have

\footnotetext{
9 "Verbal adoption is characterized by domestic actors' rhetorical endorsement of the EU's norms and reform prescriptions. This occurs when political actors' support for the EU's rules is confined at the level of rhetoric, for reasons related to willingness (...) and/or capacity (...). Legal adoption is the subsequent step to verbal compliance. It consists of attempts to pass legislation or establish formal institutions and procedures in line with the EU rules. Legal transposition may range from debates on the floor of parliament on proposed EU-friendly draft legislation, to the actual, legal adoption of comprehensive legislative measures relating to the different aspects of the EU's rules (...). The last stage of substantive compliance goes beyond verbal and legal compliance to include implementation of the EU rules. We define implementation as the process through which external norms are transposed, adhered to and enforced at the domestic level" (Elbasani 2013, 14-15).

${ }^{10}$ Law on Broadcasting (2002), Law on Higher Education and Labor Law (2005), Anti-Discrimination Law (2009), Law on Youth, Law on Social Protection, and Health Care Insurance Act (2011), Law on Public Information and Media and Electronic Media Law (2014), Law on Advertising and Law on Police (2016). With the changes made to the Criminal Code in 2012, a provision was introduced (54a) which cites sexual orientation and gender identity as aggravating circumstances for determining punishment for a "hate crime". For more information on the normative framework in Serbia regarding LGBT rights see: Jovanović 2017.

${ }^{11}$ In June 2013 the Government adopted the Strategy of Prevention and Protection against Discrimination, while the framework for realizing strategic goals was established through the Action plan for the Implementation of the Strategy for Prevention and Protection against Discrimination from 2014 to 2018. The
} 
taken place without major incidents ${ }^{12}$. The direct and intense incentive for these activities originated from the European Union, in the context of the struggle against all forms of discrimination.

This has had an impact in terms of changes in the attitudes of the citizens of Serbia toward homosexuals, which are still predominantly marked by intolerance and judgement ${ }^{13}$. A slight increase in the positive attitude toward homosexuals among the population of Serbia is clearly visible when comparing the data from the WVS $2001^{14}$, EVS $2008^{15}$, and INFORM $2017^{16}$ surveys. In answering the question asked in all three surveys: "Please tell me whether, in your opinion, the following behaviors can always be justified, can never be justified, or something in between - homosexuality", on a scale of 1-10 ( 1 = never, 10 = always), those who justified homosexuality (gave answers 6-10) comprised $5.4 \%$ in $2001,5.96 \%$ in 2008 and $13.2 \%$ in 2017. A certain progress in the tolerance of non-heterosexuals has certainly been made, but it remains open to debate to what extent this progress can be attributed to changes in the formal legal and policy spheres, or to the media exposure since "[f]ollowing cultivation theory, it is assumed that exposure to media presentation of homosexuality can lead to improved attitudes about homosexuality, but also to less acceptance" (Valić-Nedeljković et al. 2017, 90). Homonegativity is concealed using "transparent closet" (Švab and Kuhar 2014) - "reduction of homosexuality to a personal preference or lifestyle choice, for which there is in fact no place in the public identitary politics" (Sremac et al. 2015, 67).

All laws, programs and strategies have a problematic side, both in terms of their influence on the everyday life of non-heterosexuals and gender non-conforming individuals, and on the character and consequences of LGBT-affirmative political activities in Serbia.

The "corrective measures" come "from above", as a consequence of pressure from the European Union, and the Laws have been, on the part of the state, instrumentalized in the process of European integration, and not adopted as authentic legal instruments for the protection of minorities (Bilić 2016, 130). What is also problematic is the appropriate application of the laws in practice (Zekavica 2016, 355).

The article of the Criminal Code which refers to hate crimes on the basis of sexual orientation or gender identity was applied only once, in December 2018, despite a number of instances in which hate crimes against LGBT persons were reported (Isaković and Lazar 2016, $401 \mathrm{n6}, \mathrm{n} 7)$. The full implementation of the Anti-Discrimination Law,

basic goal of the Strategy is to uphold the constitutional principle of the prohibition of discrimination against vulnerable social groups, which includes LGBT persons. The Ministry of Internal Affairs adopted the Action Plan for the Improvement of work and Cooperation between the Police and the LGBT Population in February 2014. With the support of the government of Serbia and the European Council, the Improving the system of social protection for LGBT people and their families program was implemented, while the government also financed the project The creation of tolerance and understanding for the LGBT population in Serbian society.

${ }^{12}$ Besides Belgrade, LGBT manifestations were held in Niš and Novi Sad. The nation's capital has for five years in a row held two Parades (in June and in September). These events, as well as the accompanying public debates and opposition, received great media coverage. For a historical overview of the Prides in Serbia from 2001 see: Bilić 2016; Slootmaeckers 2017a.

${ }^{13}$ For more on the dominant attitude towards homosexuals in Serbia see: Jovanović 2016a, 55-72; 84-86.

${ }^{14}$ The data (for 1,200 participants from Serbia) are available for on-line analysis on the website: http://www.worldvaluessurvey.org.

${ }^{15}$ See: EVS 2010. The information on the sample (1512 participants) and the method of data compilation in Serbia are available on the website: https://infol.gesis.org/EVS/Studies/.

${ }^{16}$ The research was carried out on a representative sample of 1127 citizens of Serbia over the age of 18 . The data was gathered during the period May-June 2017. 
eight years after its adoption, is still lacking (Slootmaeckers 2017b). The absence of any adequate application, and the ineffectiveness of the judiciary when it comes to attacks on LGBT persons create a public space characterized by a culture of impunity that only incites further violent behavior.

The Serbian political elite, through "tactical Europeanization" - "an act of compliance to communicate to the EU a readiness to Europeanise by aligning oneself with certain 'European norms"' (Slootmaeckers 2017b), appropriates and exploits the Prides and thus demonstrates its alleged orientation towards Europe, without any real interest in LGBT issues, which is confirmed by the homophobic statements made by leading politicians, which are also somewhat flattering to their conservative electoral base:

I have no intention of attending. I am not someone who is thrilled with that manifestation. But regardless, it is my duty, and I managed to carry it out, to guarantee them the exercise of their freedoms and rights, and for that I am satisfied (...) I am not even considering it. And it is my right to refuse to walk where I want to and when I want to. Thank you. I do not want to (Aleksandar Vučić). ${ }^{17}$

Do not bother me with stories about human rights. The issue at hand is not human rights, but the security of the people (...). How is it possible that this is still the main topic, that we are still dealing with the gay parade as the key problem, this is ridiculous (...). Ditch the European Union if the entry ticket is the gay parade! (Ivica Dačić) ${ }^{18}$

Holding a Pride would be good for Serbia because the European Union asked for it... let's not say later on that it did not ask for it, it did... and if it were to happen, we would surely get the date for the initiation of the accession negotiations in January... but, on the other hand, an even greater pity would be if the violence that happened during the parade held in 2010 were to be repeated... I know that it is everybody's constitutional right to express their diversity, but it is my right not to go there. We should not go to the other extreme and ingratiate ourselves with everybody... why would we ingratiate ourselves with anyone? What am I supposed to do now, become gay, so that everything's pro-European? (Ivica Dačić). ${ }^{19}$

The militarization of the 2014 Pride (Ejdus and Božović 2016) transformed it into a "Ghost pride" - the participants of a ritual walk through a police-protected security zone remained invisible to the wider public, which deprived the manifestation of any political content, and thus any possible effects on society (Slootmaeckers 2017a: 14). It was almost like a "theatrical performance" for the local and foreign media and the representative of the EU on how much the political elite (who took all the "credit" for hosting the Parade) is dedicated to the European project of the struggle to end discrimination against minorities, which is a striking example of purely formal Europeanization.

The absence of any true intention of taking on the problems of the LGBT population is also manifested in the shortcomings noted in the analysis of the Action plan for the Implementation of the Strategy for Prevention and Protection against Discrimination, which refer to a

lack of consistent deadlines for implementation, as well as a lack of resources necessary for implementation. Deadlines for implementation of the measures seem unrealistic, for example, most of the measures are planned to be implemented in the last quarter of 2017

\footnotetext{
${ }^{17}$ The response of Serbian President Aleksandar Vučić to the invitation to be at the head of the Parade in 2017 (Beta 2017; our translation).

${ }^{18}$ Statement from September 2012, when Dačić was Serbian Prime Minister and Minister of Interior Affairs (Tanjug 2012; our translation).

${ }^{19}$ From an interview with Dačić conducted in 2013, cited from: Bilić 2016, 141.
} 
while at the end of 2016 the activities had not even started. There are no resources foreseen for many of the planned measures, and even if they are, it usually involves donations and projects (Jovanović 2017, 37).

All of the State and state-sponsored activities which explicitly focus on the emancipation and proper treatment of non-heterosexuals, have as their (unintended?) consequence the masking of their actual status, and are reduced to spectacles, rhetorical performances and empty promises. Without shedding light on and problematizing the everyday struggles which the members of the LGBT population are facing in Serbia today, which are to a great extent characterized by forced silence, exclusion, fear of discovery and being subjected to mistreatment and/or violence (Jarić 2011), there can be no improvement in their position. The main and clearly tangible result of the "LGBT-affirmative" actions is further consolidation and strengthening of the power of the Serbian political elite.

\section{THE CHURCH'S REALPOLITIK}

Political and Church structures in modern Serbia are interwoven, the State and Church "are already in an 'indissoluble love embrace"" (Jovanović 2018, 39). Although the Church offers itself as a main source of counter-values to the Western, that is European secular and liberal project (Buchenau 2011, 113; Jovanov and Lazar 2017), the Church seems to have realized that being silent on the LGBT issue and, thus, not impeding the State's tactical Europeanization project, is more profitable in a symbolic, as well as, a material sense.

What is reverberated constantly in the public criticism against the SOC is its exemption from paying taxes and permissibility to establish and buy properties and make profits. Each bishop of a diocese is a manager, taxed by the Patriarchate, after which he can invest funds into reasonable or profitable policies. It is impossible to determine the quantity of money circulating, but some estimates show that SOC earns over $€ 140$ million per year, which would make it the biggest profitable enterprise after Oil Industry of Serbia and Telekom Serbia. (...) The Serbian state budget pays for social, health, and pension securities for priests, monks, bishops, and other qualified employees of (all) religious communities which bulk up to $€ 8,5$ million annually (Ubiparipović 2016, 28-9).

The Government of Serbia will pay $€ 1$ million to the Serbian Orthodox Church from the State budget (...). That money is to be forwarded for taxes and employee contributions. The decision was adopted at a Government session two days ago, when the SOC submitted a request to Prime Minister Ana Brnabić because of a difficult financial situation. The money paid will be labelled, as stated, as a supplement to non-profit organizations. (...) The last time that the State allocated money for the SOC was on April 6, 2017, and it was 59.8 million dinars for the construction of the Holy Trinity Temple in Mostar, destroyed during the war in 1992, as well as half a million euros, 62.2 million dinars for the construction of The Cathedral of Saint Simeon in Berane, Montenegro (Luković 2018; our translation).

We shall try to illustrate this "Byzantine diplomacy" 20 of the Church with three recent examples that tackle the relation of the State, the Church and LGBT persons: 1) an event that followed the signing of the Brussels agreement in 2013,2) the alleviation of the ecclesial anti-LGBT rhetoric, and 3) the support of the Church for the new Serbian Prime Minister.

20 "The phrase sometimes has a pejorative meaning but in reality it captures a rational-pragmatic political style" (Perica 2006, 190). 
1) On April 19, 2013, Serbia, pressured by the EU, signed an interim agreement with Kosovo and promised "to respect the Kosovo government's control over its territory, in exchange for limited Serb autonomy in the north and Serbia's continuing official nonrecognition of Kosovo as an independent state. (...) In January 2014, Serbia was rewarded with EU candidate status" (Subotic 2013, 166). This marked the beginning of the process of the "normalization of relations", but it spawned a series of negative reactions from the Serbian Orthodox Church: "For example, as a response to the event, bishop Amfilohije prayed at the central public square in Belgrade for Kosovo and Metohija and then served a commemoration for the death of the Serbian government and the National Assembly" (Ubiparipović 2016, 31).

Aleksandar Vučić (current President, then Minister of Defense) took an unprecedented step and joined in the meeting of the Holy Synod. He received support from the Church, resulting in de-labelling the Government as being a "traitor and quisling" and the Patriarch replacing radical bishops with moderate ones (Ubiparipović 2016, 32).

Although a normalization of State-Church relations occurred, disobedient bishops, who displayed stern opposition to the Serbia-Kosovo deal, had to be punished. After a few months a news article entitled "7 Gay Bishops in the Assembly of the Serbian Orthodox Church" (Jevtić 2013) appeared. It claimed that all members of the Assembly know about seven bishops being gay, and that three more are suspected of being homosexual, continuing with a moralistic reproach of the (alleged) hypocrisy of the "traditionalistic" and "extreme right-wing" part of the high clergy, with the Metropolitanate of Montenegro and the Littoral being singled out. With the aforementioned Amfilohije as the Metropolitan bishop of this diocese, this "disciplinary act" was not surprising.

2) In recent years we have witnessed a significant change in the discourse of the church when considering the question of expressing sexual freedoms. It is especially noticeable in relation to the Pride Parade, as a symbol of the struggle of the LGBT community to increase visibility towards and tolerance of sexual difference.

Perhaps the most socially visible campaign the Church has been central in is the regulation of the private sphere, most notably the regulation of sexuality. The Church and Churchaffiliated extremist groups have been dominating the public discourse over LGBT rights, an issue that regularly comes up every year around the time of the proposed Pride Parade (Subotić 2017, 182).

Bishop Amfilohije was a vocal opponent of the Pride Parades taking place in Belgrade in 2009 and 2010 (Jovanović 2011: 705-6). He labelled Gay Pride as "a parade of shame and embarrassment" and "a parade of Sodom and Gomorrah" (Jovanović 2013, 85). The Holy Synod of the Serbian Orthodox Church issued a rather bitter statement in 2010 concerning the announcement of the holding of a gay parade (Irinej 2010). The hostility towards Pride continued in the following years. In May 2014, the Patriarch made a connection between the parade and the floods in Serbia, that was "almost humorous" as he interpreted them as "God's warning to stay away from the path of vice, wickedness and lawlessness" (Pavasović Trošt and Slootmaeckers 2015, 173). In September 2014, Patriarch Irinej referred to the costs of holding the LGBT gathering. He deviously used economic discourse for the first time in a communique coming from the Church, at a time when one of the main topics in Serbia was the austerity measures to be carried out by the Government (Jovanovic 2016b, 85). Statements by the very highest level of the church leadership manipulated public feeling about LGBT issues with ease by bundling them up with anti-EU 
discourse which was "startlingly extremist (and frequently unconstitutional)" (Pavasović Trošt and Slootmaeckers 2015, 173) and labelled homosexuality as a threat to the "traditional and spiritual values of national and religious identity" coming from the West (Valić-Nedeljković et al. 2017,88).

Against the Pride's liberal and globalizing narrative, the nationalists stressed the central role of Orthodox Christianity and the Serbian Orthodox Church in the governance of society. They used quasi-clerical discourse to describe the Pride as a "sinful," "shameful" and "satanic" attack on the Orthodox values of the "vast majority" of Serbs, and a negation of the will of the Church. The Church itself encouraged such invocations (Mikuš 2015, 23).

But, in the following years, the Church remained strangely silent when the Belgrade Prides took place without any major incidents. In 2017, one defrocked monk led a group of believers who intended to perform a religious ritual in order to clean the city square where the Pride took place (Ristović and Brkić 2017). On September 16, 2018, only groups of particularly conservative believers and monks tried to stage a counter-walk to the Pride, which the police prevented (Tanjug 2018). On both occasions there were no official comments coming from the Serbian Orthodox Church. This was two months before the Church submitted a plea to the PM for financial aid, which suggests caution on the side of the Church not to induce any kind of conflict with the government.

3) In May 2017 rumors surfaced that Ana Brnabić, then Minister of State Administration and openly lesbian, could become the new Serbian Prime Minister. The appointment of a new PM was the theme of several meetings of Church representatives and Serbian officials. One of the State officials stated that "the Church has a serious problem with the Prime Minister being a homosexual person. That is why high-ranking Church officials, who came to meetings with Government representatives, express this clearly every time" (Mastilović Jasnić 2017; our translation).

Soon the Church announced that this was a "dirty fabrication" and that the Church does not interfere with the election of the State officials:

The Serbian Orthodox Church does not peek through other people's windows and does not deal with the private life of State officials. To present the slanderous details or someone's personal temptations to the media and thus expose people to potential hazards is utterly irresponsible. The Church does not condemn anyone. It condemns only sin, only evil, and has laments for man (Tanjug 2017; our translation).

In June 2017, Ana Brnabić was appointed Prime Minister. She was warmly welcomed by the Church which only a few years ago bitterly opposed any "promotion of homosexualism" (Jovanović 2011; 2013; 2016b):

Ana Brnabic has received the full support of the leaders of the SOC for her role as Prime Minister (...) the Metropolitan of Zagreb-Ljubljana Porfirije (Perić), who arrived at the Serbian Parliament along with the Serbian Patriarch Irinej, approached Minister Brnabić as soon as he saw her in the crowd, politely greeted her, and then conveyed to her the message of the SOC. Bishop Porfirije, who is now a member of the Synod of the SOC (...), approached the Minister, grasped her by both hands and literally told her the following: "I wanted to tell you in person, you have my full support and the full support of the Church in being Prime Minister, we have the highest opinion of you. No one is opposed to it, truly. Please, do not believe any of the rumors" (Đondović 2017; our translation).

The stance of the Church one more time attests to its Realpolitik. 
Electing a lesbian Prime Minister should be read as another instance of tactical Europeanization by the State - a move which is primarily supposed to show Europe the "progressive" nature of Serbia, which will not significantly affect any changes in the lives of non-heterosexuals or the predominant attitudes towards them - "symbolic politics are only that: symbolic" (Slootmaeckers, 2017b). Nevertheless, a lesbian Prime Minister of Serbia is a social fact that cannot simply be retrieved. It increased the visibility of the lesbian population in Serbia, sparked continuing discussions on LGBT mailing lists, chat forums and the Optimist gay magazine ${ }^{21}$. Although a small one, this is certainly a step towards strengthening anti-patriarchal discourse in Serbia:

When I heard that Ana Brnabic became the Prime Minister-designate of the new Government, I spontaneously had one picture in my mind: local Serbian "housefathers and bosses", lifelong God-given politicians and other potentates in jackets and ties, priests and all other guardians of "morals and good Serbian household tradition" (which serves no other goal but to ensure that nothing ever changes and that they stay forever where they are and what they are [...]) - how they are sweating, looking at each other with disbelief, while, against their will, their "property" changes before their eyes. I have to admit that I am a little amused while imagining how they will now have to think about it, to change the language they speak, to master a kind of behavior, referring to that young woman who came to a very important position in the country, and who, with what she represents, how she looks and how she behaves, does not in any way resemble what they otherwise attribute to power; in my "painting," I imagine them losing the ground beneath their feet and the whole of their world collapsing due to the inability to conceive and digest the "disaster" that struck them (Jelisaveta Blagojević in Laufer and Jovanović 2017; our translation).

Relying on Bilić and Stubbs' (2016) argument considering the influence of EU in the post-Yugoslav space in a broader context, we think that it is of great importance to accentuate that, besides the indisputable significance of activism oriented to the extension and formalisation of rights of sexual minorities, as well as the symbolic significance of accepting an out lesbian identified person as prime minister, an exclusive focus on these aspects risks omitting an explanation of how this fight is "intimately bound with power accumulation that reflects wider power asymmetries and social trajectories of the political environment in which they operate, most notably those related to gender and sexuality" (Bilić and Stubbs 2016, 244). Therefore, the EU integration policy should imply a substantial change "in the direction of attenuating or cutting the conceptual link between homosexuality/ non-heterosexuality and Europe, and grounding sexual diversity in the local socio-political practices and historical contexts" (Ibid, 240).

\section{CONCLUSION}

As we are writing this paper, mass protests against the rule of Aleksandar Vučić and his party are taking place in many towns and cities in Serbia. We are once again receiving a confirmation of the coupling of the Church and the State as Patriarch Irinej condemns the encouragement of these protests (which recently came from professors of several Universities) as he sees no use for the people in them (Čalija 2019). Again, the Church serves the function of a symbolic legitimator of secular power.

${ }^{21}$ See: https://www.optimist.rs/category/magazin/, especially № 37 from August 2017 with Ana Brnabić on the cover, as the main topic of the issue. 
In return, the State gives the Church great leeway on many issues, except those that might jeopardize its power and its project of tactical Europeanization. Thus, the Church can frame Euro-integration as a "challenge and an opportunity for Christians" (Krstić 2015: 123). As in other countries with a predominantly Orthodox Christian population, a Church with no real political power, notwithstanding accentuated "anti-Westernism", is not to be considered a serious obstacle or threat to European integration (Makrides 2009, 221).

As for the EU, it clearly prioritizes political stability and security in the Balkans over other issues, i.e. human rights. Lack of instruments and political will on the behalf of EU to react seriously to breaches of its own principles enables political leaders to capture the state (Huszka 2017) and perpetuate the existing power structure.

So, to return one more time to the metaphor from the beginning of the paper: while LGBT persons are trying to press the gas pedal and speed-up the vehicle moving towards EU, the Church is sitting still, enjoying the benefits, and mindfully trying to divert anyone's attention from the parking brake which is still on. At the same time, politicians are driving carefully, taking into consideration both the demands of the West and those coming from the Church, which are shared by a substantial number of the populace. In fact, this is the game of the political elite which is completely oriented on one goal only: holding on to power and preserving autarchy. This is the bare interest of the political elite which is evident in the fact that it approaches the ecclesiastical attitudes and populist matrices during the period of the preparation of elections, and moves away from them in the period of firm rule when it is in its interest to comply with the principles of democracy defined in the EU's legal framework.

Acknowledgement: This paper was prepared as a part of the project "Closing the Gap Between Formal and Informal Institutions in the Balkans" (INFORM) which received funding from the European Union’s Horizon 2020 research and innovation program under grant agreement № 693537.

\section{REFERENCES}

Beta. "Organizatori Parade ponosa pozvali Vučića da stane na čelo kolone; Vučić: 'Hvala na pozivu. Neću'." Blic. July 13, 2017, https://www.blic.rs/vesti/drustvo/organizatori-parade-ponosa-pozvali-vucica-da-stanena-celo-kolone-vucic-hvala-na/p878b4y.

Bilić, Bojan, and Paul Stubbs. "Beyond EUtopian Promises and Disillusions: A Conclusion". In LGBT Activism and Europeanisation in the Post-Yugoslav Space: On the Rainbow Way to Europe, edited by Bojan Bilić, 231-248. London: Palgrave Macmillan, 2016. doi: 10.1057/978-1-137-57261-5_5.

Bilić, Bojan. "Europe $\vee$ Gays? Europeanisation and Pride Parades in Serbia". In LGBT Activism and Europeanisation in the Post-Yugoslav Space: On the Rainbow Way to Europe, edited by Bojan Bilić, 117153. London: Palgrave Macmillan, 2016. doi: 10.1057/978-1-137-57261-5_5.

Brujić, Marija. "EU Integration and the Serbian Orthodox Christianity: Socio-Anthropological Perspectives". Journal for the Study of Religions and Ideologies 16, 47 (2017): 32-46.

Buchenau, Klaus. "Orthodox Values and Modern Necessities: Serbian Orthodox Clergy and Laypeople on Democracy, Human Rights, Transition, and Globalization". In Civic and Uncivic Values: Serbia in the Post-Milošević Era, edited by Ola Listhaug, Sabrina P. Ramet, and Dragana Dulić, 111-142. Budapest; New York: Central European University Press, 2011. doi: 10.7829/j.ctt1281qx.8.

Buchenau, Klaus. "The Serbian Orthodox Church". In Eastern Christianity and Politics in the Twenty-First Century, edited by Lucian N. Leustean, 67-93. New York: Routledge, 2014. doi: 10.4324/9781315819037-14. 
Čalija, Jelena. “"Politika' se odupire napadu na dušu srpskog naroda”. Politika. January 27, 2019, http://www.politika.rs/scc/clanak/421300/Politika-se-odupire-napadu-na-dusu-srpskog-naroda.

Charrad, Mounira M. "Central and Local Patrimonialism: State-Building in Kin-Based Societies". The Annals of the American Academy 636, 1 (2011): 49-68. doi: 10.1177/0002716211401825.

Dobrijević, Irinej. "Solidarity and Social Justice: The Mission of the Serbian Orthodox Church towards European Integration". Philotheos 6 (2006): 324-332. doi: 10.5840/philotheos2006628.

Đondović, Jelena. “CRKVA BILA JASNA SPC: Želimo da Ana nasledi Vučića!” Alo. June 1, 2017, https://www.alo.rs/vesti/politika/otkrivamo-spc-zelimo-da-ana-nasledi-vucica/109503/vest.

Eisenstadt, Shmuel N. Traditional Patrimonialism and Modern Neopatrimonialism. London: Sage Publications, 1973.

Ejdus, Filip, and Mina Božović. "Europeanisation and indirect resistance: Serbian police and Pride Parades". The International Journal of Human Rights 23, $4\left(2019^{*}\right)$ : 493-511. doi: 10.1080/13642987.2016.1161212.

Elbasani, Arolda. "Europeanization travels to the Western Balkans: Enlargement strategy, domestic obstacles and diverging reforms". In European Integration and Transformation in the Western Balkans: Europeanization or business as usual?, edited by Arolda Elbasani, 3-21. London; New York: Routledge, 2013.

EVS. 2010. European Values Study 2008: Serbia (EVS 2008). GESIS Data Archive, Cologne. ZA4796 Data file Version 1.1.0. doi:10.4232/1.10186.

Freedom House. 2019. Democracy in Retreat: Freedom in the World 2019. https://freedomhouse.org/sites/ default/files/Feb2019_FH_FITW_2019_Report_ForWeb-compressed.pdf (September 15, 2019).

Huszka, Beáta. "Assessing the EU enlargement process and the dismal state of media freedom in the Balkan candidate states". EUROPP. December 18, 2017, http://blogs.lse.ac.uk/europpblog/2017/12/18/assessingthe-eu-enlargement-process-and-the-dismal-state-of-media-freedom-in-the-balkan-candidate-states/.

Irinej, Episkop bački. 2010. „Saopštenje Svetog Arhijerejskog Sinoda povodom najavâ gej-parade u Beogradu: Protiv javnog reklamiranja seksualne orijentacije.” Pravoslavlje 1046 (October): 5.

Isaković, Maja, and Žolt Lazar. „Problem diskriminacije LGBT populacije u Srbiji“. Godišnjak Filozofskog fakulteta u Novom Sadu 41, 2 (2016): 397-413. doi: 10.19090/gff.2016.2.397-413.

Jarić, Isidora. „Život između nasilja i supkulturnog geta: LGBTTIQ osobe i njihova svakodnevica u Srbiji“. Antropologija 11, 2 (2011): 141-164.

Jevtić, Željka. "Sedam gej vladika u Saboru Srpske pravoslavne crkve". Blic. October 10, 2013, https://www.blic.rs/vesti/tema-dana/sedam-gej-vladika-u-saboru-srpske-pravoslavne-crkve/s8vg1fx.

Jick, Todd D. "Mixing Qualitative and Quantitative Methods: Triangulation in Action". Administrative Science Quarterly 24, 4 (1979): 602-611. doi: 10.2307/2392366.

Jovanov, Dejan, and Žolt Lazar. "Serbian Orthodoxy Between Traditional and Universal Values: Discourse Analysis of the Journal Orthodoxy”. Sociološki pregled 51, 1 (2017): 135-156. doi: 10.5937/socpreg1701135J.

Jovanović, Miloš. „Moralistička osuda homoseksualnosti u pravoslavlju“. Teme 35, 3 (2011): 705-744.

Jovanović, Miloš. "Silence or condemnation: The Orthodox Church on homosexuality in Serbia". Družboslovne razprave 29, 73 (2013): 79-95.

Jovanović, Miloš. Identitet, religioznost, seksualnost: problem identiteta religioznih LGBT osoba u Srbiji. Novi Sad: Mediterran publishing, 2016a.

Jovanović, Miloš. "Revitalized Orthodoxy and LGBT People in Contemporary Serbia". Facta Universitatis Series: Philosophy, Sociology, Psychology and History 15, 2 (2016b): 83-92.

Jovanović, Nataša. Anti-Discriminatory Normative Framework in Serbia in the Field of LGBT rights. Beograd: Labris, 2017.

Jovanović, Vladan. "Informal Allies on a Common Mission: The Serbian State and The Orthodox Church in Recent Nation-Building Processes". Journal for the Study of Religions and Ideologies 17, 51 (2018): 38-52.

Krstić, Zoran. „Crkva i evropske integracije”. Sabornost 9, (2015): 119-125. doi: 10.5937/sabornost9-9772.

Lachmann, Richard. "American Patrimonialism: The Return of the Repressed". The Annals of the American Academy of Political and Socioal Science 636, 1 (2011): 203-230. doi: 10.1177/0002716210396814.

Laufer, Milica, and Andrea Jovanović. „Srbija više nikad neće biti ista: imenovanje Predsednice vlade Republike Srbije“. Milica Magazin. June 28, 2017, http://milicamagazine.com/sr/srbija-vise-nikad-nece-biti-ista.

Luković, Danijela. "CRKVA MOLILA ZA POMOĆ Vlada daje SPC MILION EVRA zbog 'teške finansijske situacije"”. Blic. November 11, 2018, https://www.blic.rs/vesti/drustvo/crkva-molila-za-pomoc-vlada-dajespc-milion-evra-zbog-teske-finansijske-situacije/19v4dk1.

\footnotetext{
* Published online: 31 Mar 2016.
} 
Makrides, Vasilios N. “Orthodox Anti-Westernism Today: A Hindrance to European Integration?”. International Journal for the Study of the Christian Church 9, 3 (2009): 209-224. doi: 10.1080/14742250903186935.

Mastilović Jasnić, Ivana. "SKANDALOZNO Srpska pravoslavna crkva lobira da Ana Brnabić NE BUDE PREMIJER zato što je gej”. Blic. May 12, 2017, https://www.blic.rs/vesti/politika/skandalozno-srpskapravoslavna-crkva-lobira-da-ana-brnabic-ne-bude-premijer-zato-sto/d7bqj7c (September 15, 2019).

Mikuš, Marek. "'Faggots Won't Walk through the City': Religious Nationalism and LGBT Pride Parades in Serbia". In Religious and sexual nationalisms in Central and Eastern Europe: Gods, gays, and governments, edited by S. Sremac and R. R. Ganzevoort, 15-32. Leiden, Boston: Brill, 2015. doi: 10.1163/ 9789004297791_003.

Pavasović Trošt, Tamara, and Koen Slootmaeckers. "Religion, Homosexuality and Nationalism in the Western Balkans: The Role of Religious Institutions in Defining the Nation". In Religious and sexual nationalisms in Central and Eastern Europe: Gods, gays, and governments, edited by S. Sremac and R. R. Ganzevoort, 154-180. Leiden, Boston: Brill, 2015. doi: 10.1163/9789004297791_010.

Perica, Vjekoslav. "The politics of ambivalence: Europeanization and the Serbian Orthodox Church". In Religion in an Expanding Europe, edited by Peter J. Katzenstein and Timothy Byrnes, 176-203. Cambridge: Cambridge University Press, 2006. doi:10.1017/CBO9780511491917.008.

Ristović, A. and M. Brkić. "BEOGRAD U DUGINIM BOJAMA Jelena Karleuša otvorila Paradu ponosa, šetnja kroz grad prošla mirno i veselo, policija na svakih PAR METARA”. Blic. September 17, 2017, https://www.blic.rs/vesti/beograd/beograd-u-duginim-bojama-jelena-karleusa-otvorila-paradu-ponosasetnja-kroz-grad/93ver00.

Slootmaeckers, Koen. "The litmus test of pride: analysing the emergence of the Belgrade 'Ghost' pride in the context of EU accession". East European Politics 33, 4 (2017a): 517-535. doi: 10.1080/21599165.2017.1367290.

Slootmaeckers, Koen. “Serbia’s New Lesbian Prime Minister: A Symbolic Step Forward?”. Balkanist June 17 (2017b.). http://balkanist.net/serbia-new-prime-minister/ (September 15, 2019).

Sremac, Srđan, Zlatiborka Popov Momčinović, Martina Popić and Miloš Jovanović. "For the sake of the nations: Media, homosexuality and religio-sexual nationalisms in the post-Yugoslav space". In Religious and sexual nationalisms in Central and Eastern Europe: Gods, gays, and governments, edited by S. Sremac and R. R. Ganzevoort, 52-73. Leiden, Boston: Brill, 2015. doi: 10.1163/9789004297791_005.

Subotić, Jelena. "Building Democracy in Serbia: One Step Forward, Three Steps Back". In Building Democracy in the Yugoslav Successor States: Accomplishments, Setbacks, and Challenges since 1990, edited by Sabrina P. Ramet, Christine M. Hassenstab, and Ola Listhaug, 165-91. Cambridge: Cambridge University Press, 2017. doi:10.1017/9781316848289.008.

Švab, Alenka and Roman Kuhar. "The Transparent and Family Closets: Gay Men and Lesbians and Their Families of Origin". Journal of GLBT Family Studies 10, 1-2 (2014): 15-35. doi: 10.1080/1550428X.2014.857553.

Tanjug. "Dačić: Izem ti takvu Uniju u koju je gej parada ulaznica". Blic. September 15, 2012 , https://www.blic.rs/vesti/politika/dacic-izem-ti-takvu-uniju-u-koju-je-gej-parada-ulaznica/q710bq5.

Tanjug. "SPC: Kampanja o Ani Brnabić - u njoj i patrijarh i Vučić". B92. May 15, 2017, https://www.b92.net/info/ vesti/index.php?yyyy=2017\&mm=05\&dd=15\&nav_category=11\&nav_id=1260640 (September 15, 2019).

Tanjug. "Policija zaustavila šetnju protiv Parade ponosa". B92. September 16, 2018, https://www.b92.net/ info/vesti/index.php?yyyy=2018\&mm=09\&dd=16\&nav_category=12\&nav_id=1444351 (September 15, 2019).

Ubiparipović, Stefan. "Religious Identities in Southeastern Europe: Influence of the Catholic Church in Croatia and the Serbian Orthodox Church in the 21st Century". Occasional Papers on Religion in Eastern Europe 36, 3 (2016): Article 4. http://digitalcommons.georgefox.edu/ree/vol36/iss3/4 (September 15, 2019).

Valić-Nedeljković, Dubravka, Ruard Ganzevoort, and Srdjan Sremac. "The Patriarch and the Pride: Discourse Analysis of the Online Public Response to the Serbian Orthodox Church Condemnation of the 2012 Gay Pride Parade". In Lived Religion and the Politics of (In)Tolerance, edited by Ruard Ganzevoort and Srdjan Sremac, 85-109. Cham: Palgrave MacMillan, 2017. doi: 10.1007/978-3-319-43406-3_5.

Zekavica, Radomir. "Društveni i pravni status LGBT osoba s posebnim osvrtom na slučaj Srbije”. In Pravni sistem i zaštita od diskriminacije - zbornik radova. Druga sveska, edited by Vladimir Boranijašević, 343359. Kosovska Mitrovica: Pravni fakultet Univerziteta u Prištini sa privremenim sedištem u Kosovskoj Mitrovici, 2016. 


\section{SAPUTNICI IZ SRBIJE: \\ LGBT OSOBE I CRKVA U PROCESU EVROPEIZACIJE}

Rad se bavi pitanjem dinamike odnosa između političke elite, LGBT populacije i Srpske pravoslavne crkve u ukupnom kontekstu evropeizacije Srbije. Daje se uvid u mehanizme kroz koje politička elita u Srbiji reprodukuje svoj dominantni položaj. Srpsko društvo je prikazano kao zarobljeno, a to ilustruju empirijski nalazi iz anketnog istraživanja i dubinskih intervjua. Nakon toga rad se fokusira na instrumentalizaciju pitanja seksualnih sloboda od strane političke elite za dobijanje međunarodne podrške za održavanje vlasti kroz , taktičku evropeizaciju“. Na kraju teksta razmatra se stav Srpske pravoslavne crkve u odnosu na državu i njenu navodnu podršku LGBT pitanjima. Čini se da je Crkva „shvatila“ da je ćutanje o LGBT pitanju za nju isplativije u simboličkom, ali i u materijalnom smislu.

Ključne reči: Srbija, evropeizacija, elita vlasti, LGBT populacija, Srpska pravoslavna crkva 